\title{
Shallow landslide susceptibility assessment using SINMAP in Nova Friburgo (Rio de Janeiro, Brazil)
}

\author{
Avaliação da susceptibilidade à movimentos de massa superficiais \\ utilizando SINMAP em Nova Friburgo (Rio de Janeiro, Brasil)
}

\author{
Claudia Paola Cardozo ${ }^{1}$ \\ Eymar Silva Sampaio Lopes ${ }^{1}$ \\ Antônio Miguel Vieira Monteiro ${ }^{1}$
}

Recebido em junho de 2017. Aprovado em novembro de 2018.

\begin{abstract}
Landslides cause enormous economic damage and fatalities worldwide. The "Mega disaster" in the mountainous region of Rio de Janeiro took place on $11^{\text {th }}$ and $12^{\text {th }}$ January 2011 and impacted seven municipalities. These landslide events are considered the worst disasters in Brazilian history. Landslide susceptibility zonation is one of the most important tasks in landslide risk assessment. The different approaches for landslide susceptibility modelling include: 1) Heuristics; 2) Statistical and; 3) Deterministic modelling (slope stability factor). This paper presents the comparison of different scenarios based on SINMAP (Stability INdex MAPping) to determine the shallow landslide susceptibility in Nova Friburgo. Taking into consideration the landslide locations occurring on January 2011, the accuracy of the different analyses is evaluated and significant results are highlighted.
\end{abstract}

KEYWORDS: Shallow landslides. SINMAP modelling. Slope stability. Brazil.

\section{RESUMO}

Os movimentos de massa causam enormes danos econômicos e mortes em todo o mundo. O "Mega desastre" na região montanhosa do Rio de Janeiro ocorreu nos dias 11 e 12 de Janeiro de 2011 e atingiu sete municípios. Estes eventos de movimentos de massa são considerados o pior desastre da

\footnotetext{
${ }^{1}$ Instituto Nacional de Pesquisas Espaciais - INPE. Programa de Pós-graduação em Sensoriamento Remoto, Brasil. E-mail: paola@dpi.inpe.br; eymar@dpi.inpe.br; miguel@dpi.inpe.br
} 
história brasileira. A zonação de susceptibilidade aos movimentos de massa é uma das tarefas mais importantes na avaliação do risco. As diferentes abordagens para a modelagem da susceptibilidade aos movimentos de massa incluem: 1) Modelagem Heurística; 2) Modelagem Estatística e; 3) Modelagem Determinística (fator de estabilidade de encostas). Este artigo apresenta a comparação de diferentes cenários com base no SINMAP (Stability INdex MAPping) para determinar a susceptibilidade à movimentos de massa superficiais em Nova Friburgo. Levando em consideração os locais de movimentos de massa ocorridos em Janeiro de 2011, é avaliada a precisão das diferentes análises e são destacados os resultados significativos.

PALAVRAS-CHAVE: Movimentos de massa superficiais. Modelagem SINMAP. Estabilidade de encostas. Brasil.

\section{Introduction}

Landslides are a major natural hazard, causing significant damage to properties, lives and engineering projects in all mountainous areas in the world (MARTHA et al., 2010). Brazil has a complex scenario of threats, essentially as a consequence of its size, diversity, and heterogeneous natural and social environments. There were about 150 recorded natural disasters during the period 1900-2013, whose associated impacts were also alarming: 10,052 fatalities, 71 million people affected and a loss of about USD16 billion (EM-DAT, 2013). Floods were the most frequent events (57\%), followed by mass movements (11\%) (CAMARINHA, CANAVESI and ALVALÁ, 2014).

Landslide susceptibility is the likelihood of a landslide occurring in an area based on the local terrain conditions (BRABB, 1984). It is the degree to which an area can be affected by future slope movements, i.e., an estimate of "where" landslides are likely to occur (GUZZETTI et al., 2006).

Landslide susceptibility zonation is one of the most important tasks in landslide risk assessment. The different approaches for landslide susceptibility modelling includes: 1) Heuristics (e.g., index-based approach and an analytical hierarchical process approach); 2) Statistical (statistical index, certainty factor, probability based methods, weight of evidence 
modelling, multiple linear regression and logistic regression analysis) and; 3) Process-based or deterministic modelling (slope stability factor) (KURIAKOSE, 2010). Various terrain stability models have been created in such a way that they incorporate the effects of important processes that affects shallow landsliding. Furthermore, they remain simple enough to allow calibration of their factors and validation of their results using existing landslide inventories. One of these terrain stability models, called SINMAP (Stability INdex MAPping) has been tested under different geological and hydrological conditions by several authors (Morrissey, Wieczorek and Morgan, 2001; Zaitchik and Van Es, 2003; Calcaterra, de Risso and di Martire, 2004; Silva, 2006; Tarolli and Tarboton, 2006; Meisina and Scarabelli, 2007; Lopes et al., 2007; Nery and Vieira, 2012; Michel, Kobiyama and Goerl, 2014; Preti and Letterio, 2015; Terhorst and Jaeger, 2015; Abascal and González Bonorino, 2015; Rabonza et al., 2016) and it has proved to be highly reliable in predicting slope instabilities. The consistency of SINMAP has been tested by Zizioli et al. (2013) who have compared its performance against other models as SHALSTAB, TRIGRS, and SLIP, resulting in a similar global accuracy for all models.

The aim of this study was to assess the shallow landslide susceptibility through the SINMAP approach to better understand slope stability in Nova Friburgo.

This paper is organized as follows: the next section presents a broad depiction of the 2011 Nova Friburgo disaster caused by landslide events. In section three, features of the Stability Index Mapping (SINMAP) method are described. Section four refers to the characteristics of the study area. Later, section five details the data sources and methodology used to determine the shallow landslide susceptibility. In section six, we present the results and discuss our findings. Finally, section seven formalizes some final remarks.

\section{The 2011 Nova Friburgo Disaster}


The "Mega disaster" in the mountainous region of Rio de Janeiro took place on $11^{\text {th }}$ and $12^{\text {th }}$ January 2011 (Figure 1) and impacted seven municipalities: Areal, Bom Jardim, Nova Friburgo, São José do Vale do Rio Preto, Sumidouro, Petrópolis and Teresópolis. This event is considered the worst disaster in Brazilian history, not only because of the human fatalities that it caused, but also because of the significant losses and economic damage with considerable negative implications on the quality of life of the survivors and on the economic activity of the entire region (WORLD BANK, 2012). This hazardous event was triggered by extremely heavy precipitation. During two rainstorm days, $241.8 \mathrm{~mm}$ were accumulated in a 24 -h period (DOURADO, ARRAES and SILVA, 2012). Although it is considered the most destructive landslides ever registered in Brazil, similar events had previously occurred in Rio de Janeiro in 1966, 1967, 1988, 1996 and 2010 (Barata, 1969; Costa Nunez, 1969; Jones, 1973; Coelho Netto et al. 2011) and particularly in the Nova Friburgo municipality in 1924, 1940, 1977, 1979, 2007 and 2011 (DRMRJ, 2015).

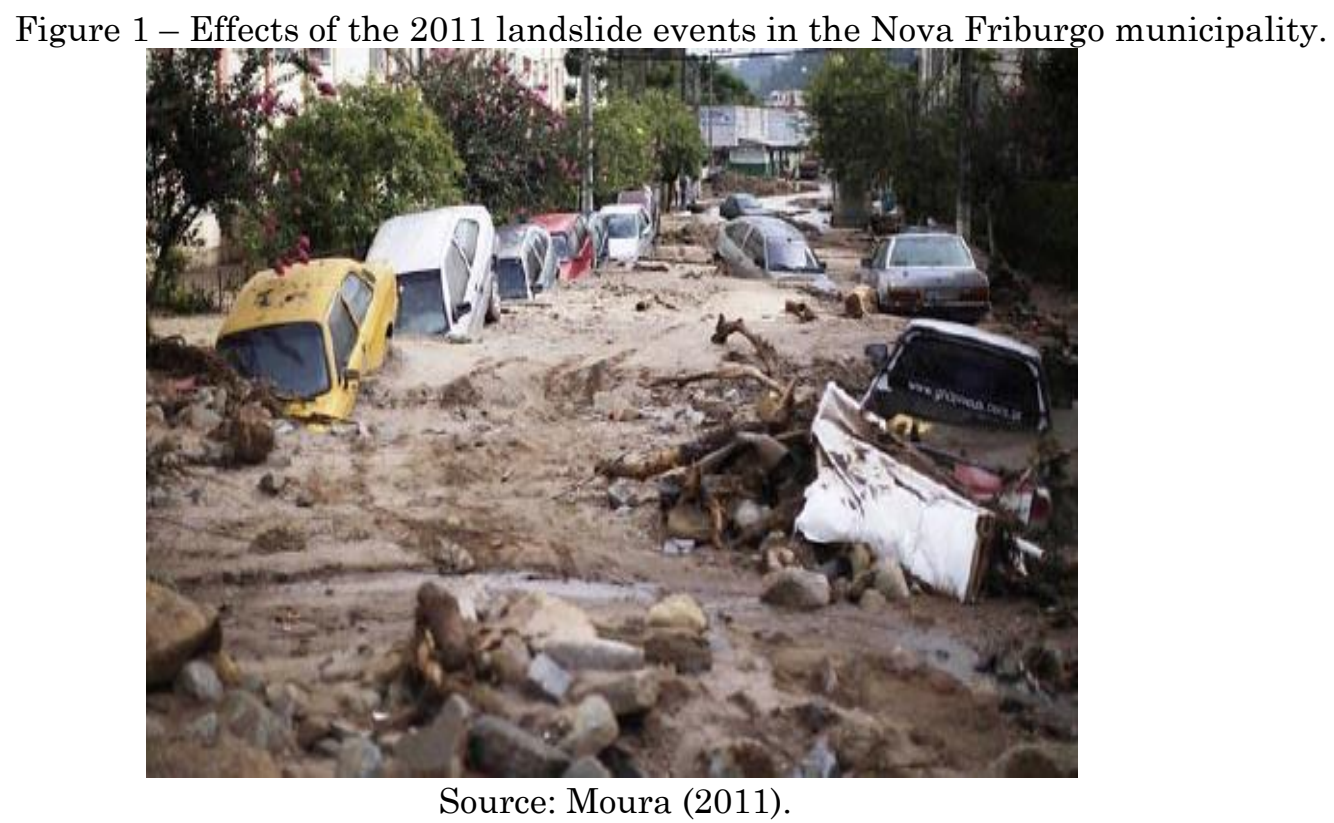


Natural disasters do not affect people equally as if by an arbitrary stroke of nature. Instead, the disaster impact is contingent on the vulnerability of affected people, which can and often does systematically differ across economic class, ethnicity, gender and other factors (NEUMAYER and PLÜMPER, 2007). Recently, Cardozo et al. (2017) have carried out a broad assessment of human fatalities in the 2011 Nova Friburgo disaster. The authors pointed out that the total number of landslide-related deaths was 434 (205 women and 228 men). The cause of death for all the victims was mechanical asphyxia caused by burial. The largest density of fatalities was concentrated in the centre of the municipality, coincident with the urban area; while landslides were prone to occupy a larger area including both urban and rural zones (Figure 2).

Figure 2 - Spatial distribution of the fatalities density (fatalities per $\mathrm{km}^{2}$ ) and landslides location in the 2011 Nova Friburgo disaster.

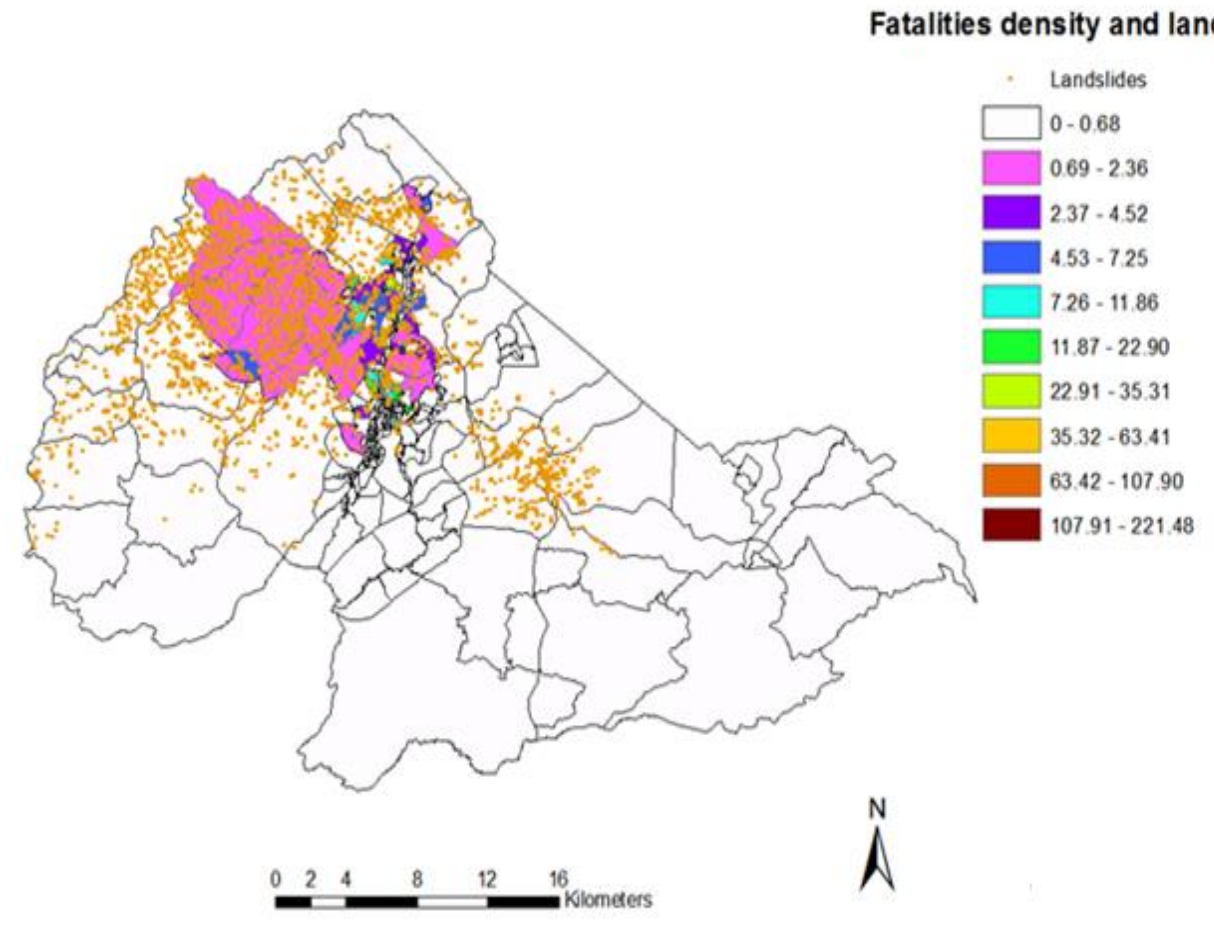

Source: Cardozo et al. (2017).

The mean age of victims was 35 years old and the age range of affected people was 0 to 90 years old. Fatalities were linked to the existence of both 
intra-urban differentials in exposition and vulnerability, which also shaped differentials in response capacity of citizens. Nearby half of the people who lost their lives in this landslide-related disaster in Nova Friburgo were the youngest and oldest. Approximately $25 \%$ of the people who died were children and adolescents between 0 to 19 years old. On the other extreme, $19 \%$ of fatalities were persons 60 years old or older. These results are in concordance with Cutter, Boruff and Lynn (2003), who pointed out that those individuals at the extremes of demographic groups are the most affected by disasters.

\section{The Stability Index Mapping Model}

SINMAP (Stability Index Mapping) methodology published by Tarboton (1997) and Pack, Tarboton and Goodwin (1999) is based upon the infinite slope stability model that balances the destabilizing components of gravity and the restoring components of friction and cohesion on a failure plane parallel to the surface of the ground neglecting edge effects. SINMAP derives its terrain stability classification as a Factor of Safety (FS) from inputs of topographic slope and specific catchment area and from parameters quantifying material properties (such as strength) and climate (primarily a hydrologic wetness parameter) (PACK, TARBOTON and GOODWIN, 2005; MEISINA and SCARABELLI, 2007) (Equation 1). Each of these parameters is delineated on a numerical grid over the study area.

$$
\mathrm{FS}=\frac{\mathrm{C}_{\mathrm{r}}+\mathrm{C}_{\mathrm{s}}+\cos ^{2} \theta\left[\rho_{\mathrm{s}} \mathrm{g}\left(\mathrm{D}-\mathrm{D}_{\mathrm{w}}\right)+\left(\rho_{\mathrm{s}} \mathrm{g}-\rho_{\mathrm{w}} \mathrm{g}\right) \mathrm{D}_{\mathrm{w}}\right] \tan \phi}{\mathrm{D} \rho_{\mathrm{s}} \mathrm{g} \sin \theta \cos \theta}
$$

where FS is Factor of Safety; $\mathbf{C}_{\mathbf{r}}$ is root cohesion $\left[\mathrm{N} / \mathrm{m}^{2}\right]$; $\mathbf{C}_{\mathbf{s}}$ is soil cohesion $\left[\mathrm{N} / \mathrm{m}^{2}\right] ; \boldsymbol{\theta}$ is slope angle; $\boldsymbol{\rho}_{\mathrm{s}}$ is wet soil density $\left[\mathrm{kg} / \mathrm{m}^{3}\right] ; \boldsymbol{\rho}_{\mathrm{w}}$ is the density of water $\left[\mathrm{kg} / \mathrm{m}^{3}\right]$; $\mathbf{g}$ is gravitational acceleration $\left[9.81 \mathrm{~m} / \mathrm{s}^{2}\right]$; $\mathbf{D}$ the vertical soil depth [m]; $\mathbf{D}_{\mathbf{w}}$ the vertical height of the water table within the soil layer [m] and; $\boldsymbol{\phi}$ the internal friction angle of the soil $\left[{ }^{\circ}\right]$. The slope angle $\boldsymbol{\theta}$ is the arc 
tangent of the slope, $\mathbf{S}$, expressed as a decimal drop per unit horizontal distance.

The Stability Index (SI) is the Factor of Safety that gives a measure of the magnitude of destabilizing factors (e.g. increased wetness due to road drainage, local loading, or local enhancement of pore pressures due to soil pipe effects) required for instability. Figure 3 illustrates the geometry assumed in Equation 1.

Figure 3 - Infinite slope stability model schematic. Soil thickness, $\mathbf{h}[\mathrm{m}]$ and vertical soil depth, $\mathbf{D}[\mathrm{m}]$ are related as follows, $\mathbf{h}=\mathbf{D} \cos \boldsymbol{\theta}$.

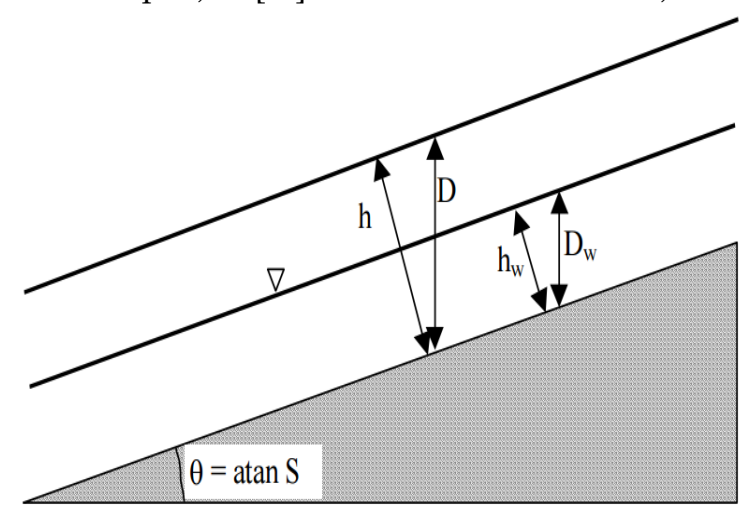

Source: Pack et al. (2005).

The stability classes adopted by SINMAP are shown in Table 1.

The SINMAP's concept is based on field information for calibration; by consequence, the model's output depends heavily on accurate positioning of known landslides (MEISINA and SCARABELLI, 2007).

Table 1- Stability classes in the SINMAP model.

\begin{tabular}{c|c|c|c}
\hline $\begin{array}{c}\text { Stability } \\
\text { Index }\end{array}$ & Stability classes & Parameter range & $\begin{array}{c}\text { Possible influence of } \\
\text { factors not modelled }\end{array}$ \\
\hline SI $>1.5$ & $\begin{array}{c}\text { Unconditionally } \\
\text { stable }\end{array}$ & $\begin{array}{c}\text { Range cannot model } \\
\text { instability }\end{array}$ & $\begin{array}{c}\text { Significant destabilizing } \\
\text { factors are required for } \\
\text { instability }\end{array}$ \\
\hline $1.5>$ SI $>1.25$ & Moderately stable & $\begin{array}{c}\text { Range cannot model } \\
\text { instability }\end{array}$ & $\begin{array}{c}\text { Moderate destabilizing } \\
\text { factors are required for } \\
\text { instability }\end{array}$ \\
\hline $1.25>$ SI $>1.0$ & Quasi-stable & $\begin{array}{c}\text { Range cannot model } \\
\text { instability }\end{array}$ & $\begin{array}{c}\text { Minor destabilizing } \\
\text { factors could led to } \\
\text { instability }\end{array}$ \\
\hline
\end{tabular}


Table 1- continued

\begin{tabular}{c|c|c|c}
\hline $\begin{array}{c}\text { Stability } \\
\text { Index }\end{array}$ & Stability classes & Parameter range & $\begin{array}{c}\text { Possible influence of } \\
\text { factors not modelled }\end{array}$ \\
\hline $1.0>$ SI $>0.5$ & $\begin{array}{c}\text { Lower threshold of } \\
\text { stability }\end{array}$ & $\begin{array}{c}\text { Pessimistic half of } \\
\text { range required for } \\
\text { instability }\end{array}$ & $\begin{array}{c}\text { Destabilizing factors are } \\
\text { not required for } \\
\text { instability }\end{array}$ \\
\hline $0.5>$ SI $>0$ & $\begin{array}{c}\text { Upper threshold } \\
\text { of stability }\end{array}$ & $\begin{array}{c}\text { Optimistic half of } \\
\text { range required for } \\
\text { instability }\end{array}$ & $\begin{array}{c}\text { Stabilizing factors may } \\
\text { be responsible for } \\
\text { stability }\end{array}$ \\
\hline SI $<0$ & Unconditional & $\begin{array}{c}\text { Range cannot model } \\
\text { instability }\end{array}$ & $\begin{array}{c}\text { Stabilizing factors are } \\
\text { required for stability }\end{array}$ \\
\hline
\end{tabular}

Source: Michel et al. (2014).

\section{Study Area}

The municipality of Nova Friburgo is located in the mountainous region of the Rio de Janeiro State, Brazil (Figure 4) and covers a surface area of $933,415 \mathrm{~km}^{2}$. It is situated in the "Serra dos Órgãos", a local name that designates a higher portion of the mountains called "Serra do Mar".

Figure 4 - Location map of the study area, Nova Friburgo, Rio de Janeiro State, Brazil.

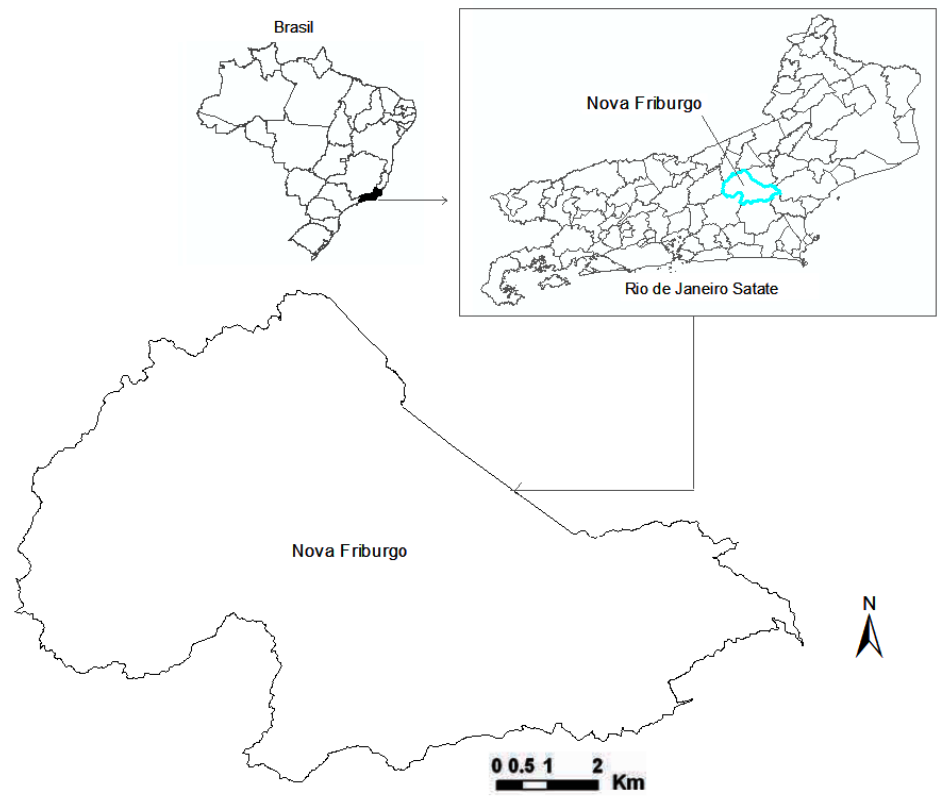

Source: Prepared by the authors. 
The elevation ranges between 636 and $1587 \mathrm{~m}$ above mean sea level. In 2010, the study area had a population of 182,082 inhabitants (195.07 inhabitants per kilometer square) (IBGE, 2010). According to Coelho Netto et al. (2011) about 90\% lived mainly in the urban zones.

The zone has a predominately High-Altitude Tropical Climate with an average temperature of $16^{\circ} \mathrm{C}$. This area was originally the Tropical Atlantic Rainforest, but currently is fragmented and much degraded, especially around the urban areas. Nova Friburgo is the rainiest area of the state with an average annual precipitation of around $2500 \mathrm{~mm}$ in the highest areas, decreasing progressively to the north up to $1300 \mathrm{~mm}$ (COELHO NETTO et al., 2011).

In this mountainous region of Rio de Janeiro, the valley bottoms are narrow and develop along persistent tectonic fractures in which only the larger rivers are able to generate fluvial deposits where the majority of the population is located. Adjacent to these valleys, escarpments with rocky outcroppings and steeps slopes (more than 35 degrees) are common. These can present deposits of talus or colluvium rich in rock blocks at the base. On the other hand, in the "Serra dos Órgãos" landscape, there are also many areas where intramontane hills grade to slopes of slighter declivity (between 15 and 35 degrees). In these areas the regolith are composed by thick saprolitic and colluvial deposits that together can reach up to $10 \mathrm{~m}$ in deep weathering profiles (saprolites) up to $50 \mathrm{~m}$ in thickness. The predominant rock in much of mountainous region of Rio de Janeiro State is an equigranular granite with grains between 3 and $5 \mathrm{~nm}$, basically composed of quartz, K-feldspar and biotite (AVELAR et al., 2011). This rock belongs to the Proterozoic Eon and it is inserted in the regional geological maps as the Serra dos Órgãos Batolite and Nova Friburgo Granite units (DRM-RJ, 1982).

The area offers a good opportunity to test the applicability of the SINMAP methodology since the approach applies to shallow 
translational landsliding phenomena (PACK, TARBOTON and GOODWIN 2005). Thus, this model can be very useful for tracing local hydrological conditions which determine the potential slide risk essentially.

\section{Data Sources and Methodology}

Figure 5 shows the methodology adopted for the shallow landslide susceptibility assessment. The SINMAP approach for stability index is described in the following steps.

The testing was carried out in SINMAP 2.0 which uses ArcGIS software environment, version 9.0 or higher. To identify the most and least susceptibility zones, Stability Index (SI) was mapped based on six classes: stable, moderately stable, quasi-stable, lower threshold of stability, upper threshold of stability, and unstable. According to Pack, Tarboton and Goodwin (2005) "lower threshold" and "upper threshold" characterize regions where, according to the parameter uncertainty ranges quantified by the model, the probability of instability is less than or greater than $50 \%$ respectively.

\subsection{Topographic data and landslide inventory}

The study used a 10 m-resolution digital elevation model (DEM), provided by the Brazilian Institute of Geography and Statistics (IBGE) from which the necessary input information was obtained (slope, flow direction and specific catchment area). Pits in DEM were eliminated using a "flooding" approach by raising the elevation of each pit grid cell within the DEM to the elevation of the lowest pour point on the perimeter of the pit (PACK, TARBOTON and GOODWIN, 2005).

A previous landslide inventory of 2011 had been completed for the study area using a Geoeye-1 satellite image of 2011 and a semi-automatic 
approach. A total of 2272 fresh scars were recognized. Landslides were classified as shallow "debris flow", "slides" and "debris slides".

Figure 5-Generalized methodology flowchart for shallow landslide susceptibility mapping using SINMAP.

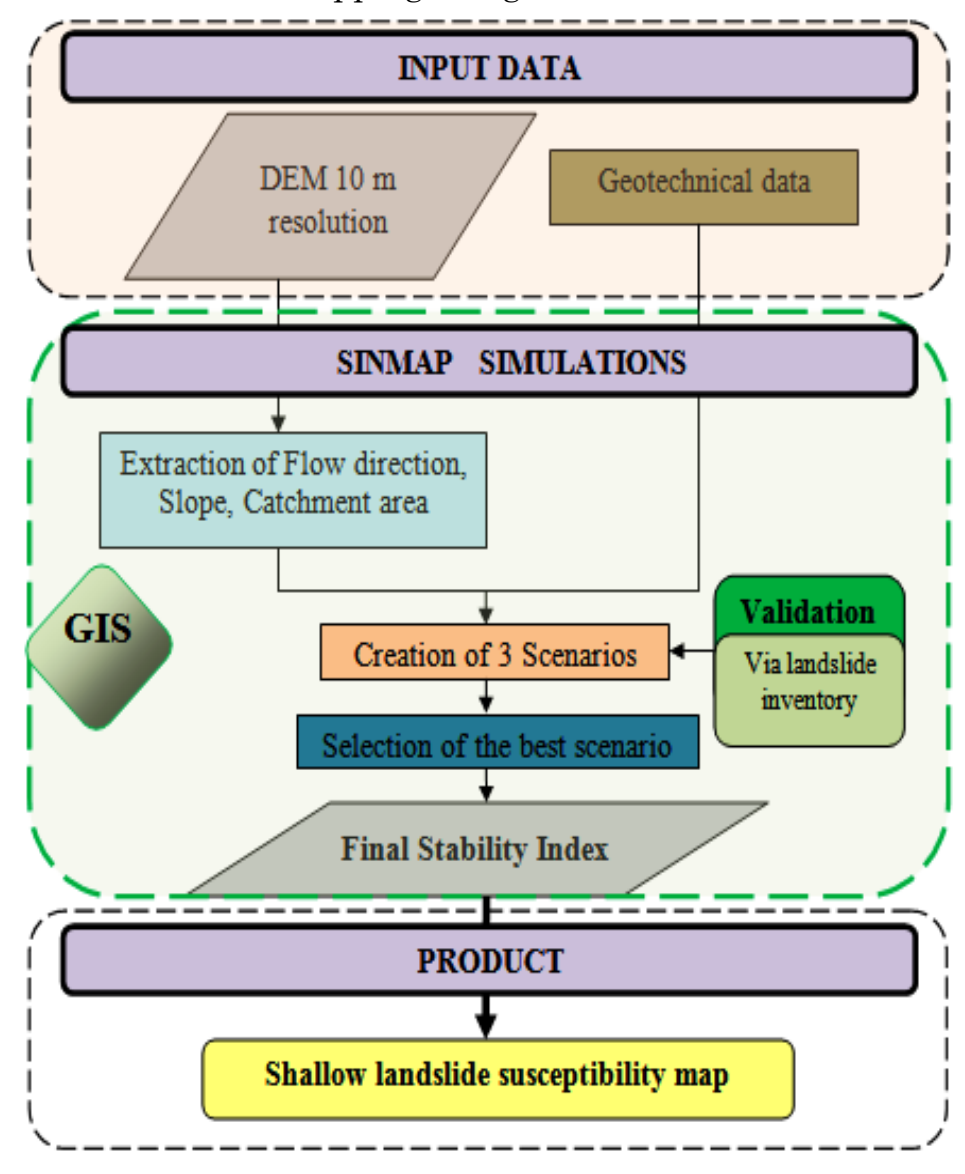

Source: Prepared by the authors.

Since the SINMAP methodology applies to failure locations within a zone of initiation, in the present study an initiation point location of each landslide was identified. Consequently, this last inventory map was used to test the accuracy and model prediction skill of SINMAP approach by comparing observed landslide locations with the model predictions.

\subsection{Geotechnical data}

Since soil samples collection in situ and laboratory tests were outside the scope of this paper, soil and vegetation parameters were obtained from 
the literature values. We found a difficulty to obtain specific values for the study area, therefore there were considered parameter's values of the mountain ranges "Serra do Mar" from various authors (COSTA NUNEZ, 1969; WOLLE and PEDROSA, 1981; DE CAMPOS, ANDRADE and VARGAS, 1992; WOLLE and CARVALHO, 1994; GUIMARÃES, 2000; AMARAL, 2007; LOPES et al., 2007; AVELAR et al., 2011; NERY, 2011; NERY and VIEIRA, 2012; DOURADO and ROIG, 2013).

SINMAP methodology allows to adjust parameters for geographic "calibration regions" based upon soil, vegetation, or geologic data. In this study, a single calibration region was used because no detailed data were available. However, three susceptibility scenarios were tested by varying parameters of soil cohesion and internal angle of friction (Table 2). In all scenarios, a wet soil density value of 2000 was used $\left(\mathrm{kg} / \mathrm{m}^{3}\right)$. Also, a uniform soil thickness throughout the study area of $1.5 \mathrm{~m}$ was assumed.

Root systems contribute to soil strength by providing an additional cohesion component. The vegetation in the area is mainly represented by forest with root systems that vary widely in time and space. Coelho Netto et al. (2011) indicate that forest patches are represented by a secondary ecological succession of plants with shallow roots and variable degradation states. Due to the difficulty to find a root cohesion value for the study area, we assumed a mean value of $0.003 \mathrm{~N} / \mathrm{m}^{2}$ according to values cited by Kozciak (2005) and Tabalipa and Fiori (2008).

Table 2 - Input data set used in the 3 susceptibility scenarios for Stability Index.

\begin{tabular}{c|c|c|c}
\hline \multirow{2}{*}{ Parameters } & \multicolumn{3}{|c}{ Scenarios } \\
\cline { 2 - 4 } & $\mathbf{1}$ & $\mathbf{2}$ & $\mathbf{3}$ \\
\hline $\boldsymbol{\phi}_{\min }^{\prime}\left[^{\circ}\right]$ & 28 & 25 & 30 \\
\hline $\boldsymbol{\phi}_{\max }^{\prime}\left[{ }^{\circ}\right]$ & 39 & 45 & 49 \\
\hline $\mathrm{C}_{\min }\left[\mathrm{N} / \mathrm{m}^{2}\right]$ & 0,12 & 0.15 & 0.27 \\
\hline $\mathrm{C}_{\max }\left[\mathrm{N} / \mathrm{m}^{2}\right]$ & 0,21 & 0.36 & 0.98 \\
\hline $\mathrm{C}_{\mathrm{r}}\left[\mathrm{N} / \mathrm{m}^{2}\right]$ & 0.003 & 0.003 & 0.003 \\
\hline $\mathrm{T} / \mathrm{R}_{\min }[\mathrm{m}]$ & 68 & 68 & 68 \\
\hline $\mathrm{T} / \mathrm{R}_{\max }[\mathrm{m}]$ & 213 & 213 & 213 \\
\hline
\end{tabular}

Source: Prepared by the authors. 
Internal angle of friction is a measure of the shear strength of soil due to friction determined in the laboratory using direct shear strength or triaxial stress test (RABONZA et al., 2016). The equation used to determine the dimensionless cohesion combines root and soil cohesion. Theoretically, this is the ratio of the cohesive strength of the roots and soil relative to the weight of a saturated thickness of soil (PACK, TARBOTON and GOODWIN, 2005) (Equation 2).

$$
C=\frac{\left(\mathrm{C}_{\mathrm{r}}+\mathrm{C}_{\mathrm{s}}\right)}{\mathrm{h} \rho_{\mathrm{s}} \mathrm{g}}
$$

where $\mathbf{C}$ is cohesion; $\mathbf{C}_{\boldsymbol{r}}$ is root cohesion $\left[\mathrm{N} / \mathrm{m}^{2}\right] ; \mathbf{C}_{\mathbf{s}}$ is soil cohesion $\left[\mathrm{N} / \mathrm{m}^{2}\right] ; \mathbf{h}$ is soil thickness $[\mathrm{m}] ; \boldsymbol{\rho}_{\mathrm{s}}$ is wet soil density $\left[\mathrm{kg} / \mathrm{m}^{3}\right]$ and; $\mathbf{g}$ is gravitational acceleration $\left[\mathrm{m} / \mathrm{s}^{2}\right]$.

The ratio steady state recharge $\mathbf{R} / \mathbf{T}$ soil transmissivity combines both climate and hydrogeological factors (MEISINA and SCARABELLI, 2007). It quantifies the relative wetness in terms of assumed steady state recharge relative to the soil's capacity for lateral drainage of water (PACK, TARBOTON and GOODWIN, 2005). The quantity $\mathbf{R}$ is the effective recharge for a critical period of wet weather likely to trigger landslides, while the transmissivity $\mathbf{T}$ relates the hydraulic conductivity of the soil and the soil depth in meters. Also these parameters were obtained from the literature values.

\section{Results and Discussion}

Advancements in computer technology, the increased availability of thematic information in digital format, the improved ability to manage landslide and geomorphological information in geographical information 
systems have facilitated the preparation of landslide assessments (ROSSI et al., 2010).

Different landslide susceptibility maps were created from the three tested susceptibility scenarios. Scenario 1, which considered the highest condition of soil saturation, proved to be the most accurate of the simulations. According to Chung and Fabbri (2003), it is important to carry out the validation of prediction models. Without some kind of validation, the model's predictive capabilities would be unknown and it would be of little scientific value.

SINMAP-scenario 1, predicted correctly 55\% (1234) of landslide locations within the unstable zone against 30\% (680) for scenario 2 and 3 respectively. Likewise, 35\% (798) of all inventoried landslides were predicted within critical zone of stability (i.e., upper and lower threshold stability classes) in scenario 1 (Table 3). The final map revealed that zones with unstable and critical conditions for stability represented $74 \%\left(934 \mathrm{~km}^{2}\right)$ of the territory (Figure 6 and 7).

Table 3 - Results of the susceptibility scenarios tested in SINMAP, ( $\mathrm{S}=$ Stable;

MS = Moderately stable; QS = Quasi stable; LT = Lower threshold;

$\mathrm{UT}=$ Upper threshold; $\mathrm{U}=$ Unstable).

\begin{tabular}{|c|c|c|c|c|c|c|c|}
\hline Characteristic & \# & $\begin{array}{c}\mathrm{S} \\
\mathrm{SI}>1.5\end{array}$ & $\begin{array}{c}\mathrm{MS} \\
1.5>\mathrm{SI}>1.25\end{array}$ & $\begin{array}{c}\mathrm{QS} \\
\mathbf{1 . 2 5}>\mathrm{SI}>\mathbf{1 . 0}\end{array}$ & $\underset{1.0>\mathrm{SI}>0.5}{\mathrm{LT}}$ & $\begin{array}{c}\mathrm{UT} \\
0.5>\mathrm{SI}>0\end{array}$ & $\underset{\mathrm{SI}<0}{\mathrm{U}}$ \\
\hline Area $\left(\mathrm{km}^{2}\right)$ & \multirow{2}{*}{1} & 176.13 & 56.00 & 97.13 & 168.78 & 264.64 & 500.43 \\
\hline $\begin{array}{c}\mathrm{N}^{\circ} \text { landslides } \\
(\%)\end{array}$ & & $\begin{array}{l}83 \\
(3) \\
\end{array}$ & $\begin{array}{l}43 \\
(2) \\
\end{array}$ & $\begin{array}{l}114 \\
(5)\end{array}$ & $\begin{array}{l}233 \\
(10) \\
\end{array}$ & $\begin{array}{l}565 \\
(25) \\
\end{array}$ & $\begin{array}{c}1234 \\
(55) \\
\end{array}$ \\
\hline Area $\left(\mathrm{km}^{2}\right)$ & \multirow{2}{*}{2} & 145.75 & 44.24 & 77.82 & 302.91 & 394.49 & 297.91 \\
\hline $\begin{array}{c}\mathrm{N}^{\circ} \text { landslides } \\
(\%)\end{array}$ & & $\begin{array}{l}71 \\
(3) \\
\end{array}$ & $\begin{array}{l}22 \\
(1) \\
\end{array}$ & $\begin{array}{l}78 \\
(4) \\
\end{array}$ & $\begin{array}{l}440 \\
(19) \\
\end{array}$ & $\begin{array}{l}981 \\
(43) \\
\end{array}$ & $\begin{array}{l}680 \\
(30) \\
\end{array}$ \\
\hline Area $\left(\mathrm{km}^{2}\right)$ & \multirow{2}{*}{3} & 199.14 & 64.69 & 111.35 & 260.14 & 329.88 & 297.91 \\
\hline $\begin{array}{c}\mathrm{N}^{\circ} \text { landslides } \\
(\%)\end{array}$ & & $\begin{array}{l}98 \\
(4)\end{array}$ & $\begin{array}{l}65 \\
(3)\end{array}$ & $\begin{array}{l}146 \\
(6)\end{array}$ & $\begin{array}{l}422 \\
(19)\end{array}$ & $\begin{array}{l}861 \\
(38)\end{array}$ & $\begin{array}{l}680 \\
(30)\end{array}$ \\
\hline
\end{tabular}

Source: Prepared by the authors. 
In the scenario 1 , the largest landslide density (0.98) was found in the unstable category that represents about $40 \%$ of the study area. About the $34 \%$ of the study area was classified with Stability Index (SI) below one (upper threshold and lower threshold classes) (Figure 7).

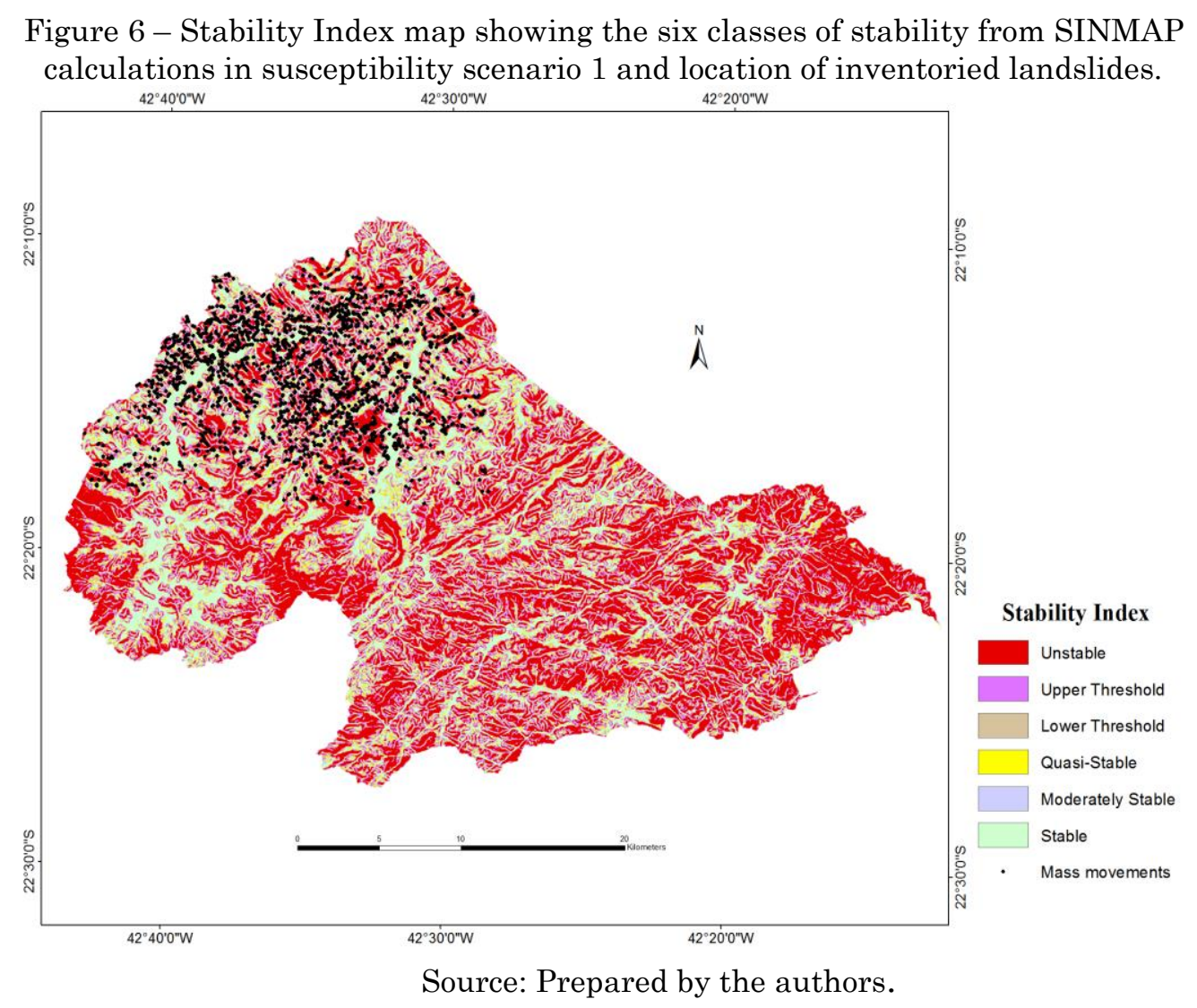

Despite of good model predictions, the scenario 1 showed that $10 \%$ (240) of landslide locations were not well predicted. That is, 3\% (83) coincided with the stable class, $2 \%$ (43) corresponded with moderately stable class and $5 \%$ (114) was concurrent with the quasi-stable class (Table 3). According to Pack, Tarboton and Goodwin (2005), the reason for these results may be twofold: 1) the bedrock, superficial geology and landslide processes are more complex and, 2) the DEM data fails to pick up many of the small but critical slopes. In addition, it also could be attributed to some error in the accuracy of landslide initiation locations. 
Figure 7 - Prediction accuracy of SINMAP model in the three susceptibility scenarios.

A) Scenario 1; B) Scenario 2 and, C) Scenario 3, (red squares = landslide density;

B) light blue bars = area of the stability classes).
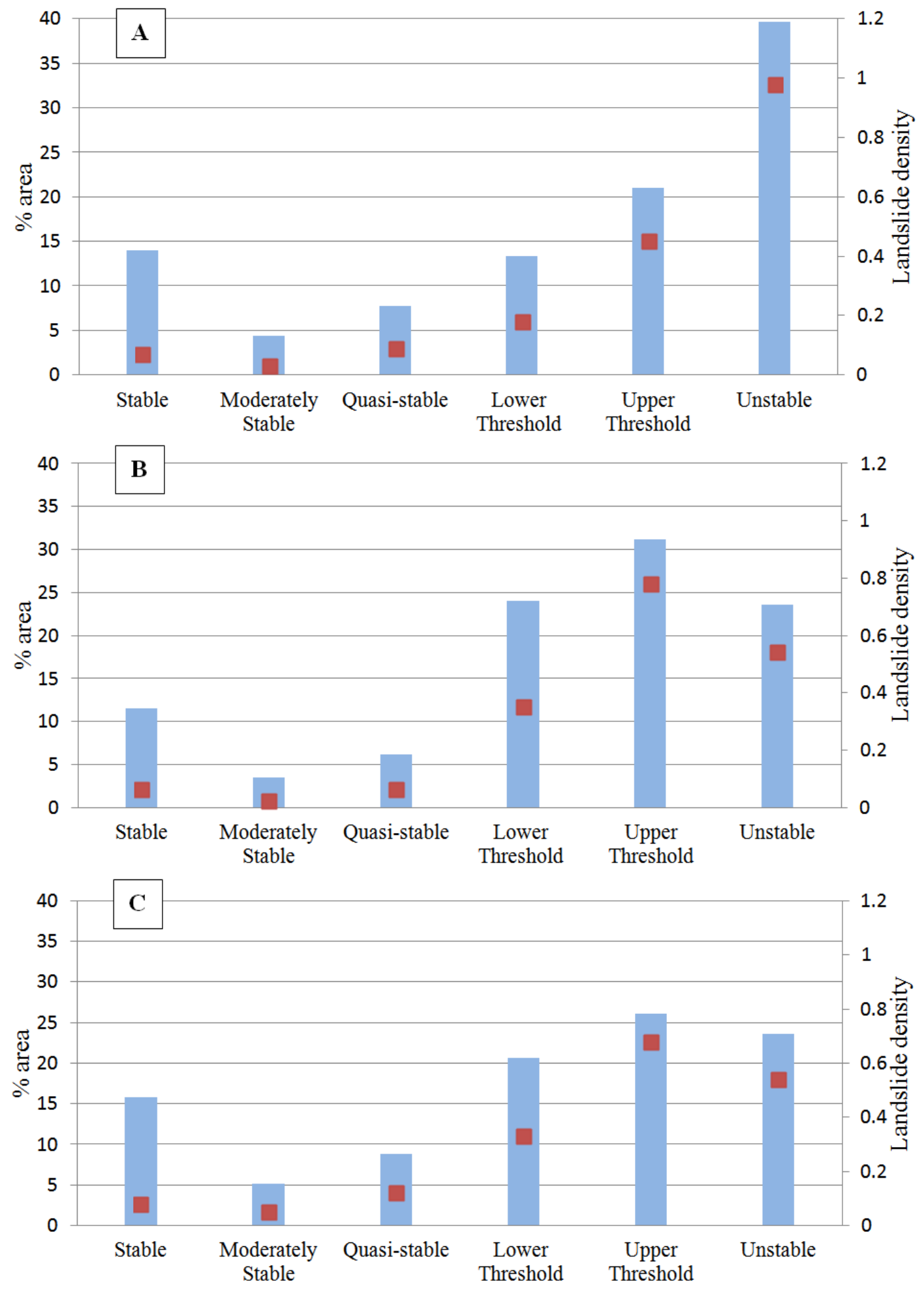

Source: Prepared by the authors.

Rev. Bras. de Cartografia, vol. 70, n. 4, outubro/dezembro, 2018. pp. 1206 - 1230. 
On the other hand, the final stability index map (Figure 6) also showed that many areas classified as unstable and critical for stability were not verified during the rainfall-induced landslides of January 2011.

These findings might be analysed as an overestimation that may be attributed to the assumption of homogeneous properties, uniform landslide thickness and spatial and temporal uniformity of rainfall in the model (MORRISSEY, WIECZOREK and MORGAN, 2001). Coelho Netto et al. (2011) suggested that rainfall was spatially non-uniform during January $11^{\text {th }}$ and $12^{\text {th }}$ in Nova Friburgo. In fact, the central area of the municipality registered the lowest amount of rainfall, while having the highest density of landslides.

Inspection of the wetness map and S-A plot (Figure 8) revealed that most of landslides were located within the areas modelled as being wet. These findings are according to the technical report of the Geological Survey of Rio de Janeiro, in which it is mentioned that the surface residual soils-which occupy $744,21 \mathrm{~km}^{2}$ of the municipality of Nova Friburgo-with slopes greater than 30 degrees possess great potential for the occurrence of landslides; in fact, they are rapidly saturated during periods of heavy rain and are propagated easily as debris or soil flow. In addition, human settlements on steep slopes increase the risk of mass wasting processes (DRM-RJ, 2015). Figure 8-B shows that slopes between 15 degrees and 58 degrees had a factor of safety below 1, meaning critical zones of stability prone to landslide occurrence with upslope catchment areas below $10^{5} \mathrm{~m}^{2}$. The most unstable areas (factor of safety below 0) were recorded on slope angles greater than 23 degrees. These results are in agreement with Coelho Netto et al. (2011), who pointed out that landslides occurred in slope segments with an average slope of 19 degrees and maximum slope of 65 degrees. In the D'Antas creek basin, the area of Nova Friburgo most affected by the 2011 landslides, the average slope angle was 32 degrees (COELHO NETTO et al., 2017). Likewise, Northern zones such as Riogandina and Conselheiro Paulino registered landslides on slopes steeper than 30 degrees (DRM-RJ, 2015). 
The final model proved to have a good performance with the dataset used. However, as reported by Meisina and Scarabelli (2007), the data required to implement the SINMAP model include soil and climate properties that can be highly variable in both space and time.

Figure 8-A) Wetness map and, B) Relationship between slope (S) and contributing area (A) in the Scenario 1 of SINMAP (Lines denote the six SI classes shown in the associated Stability Index map; blue points indicate inventoried landslides).
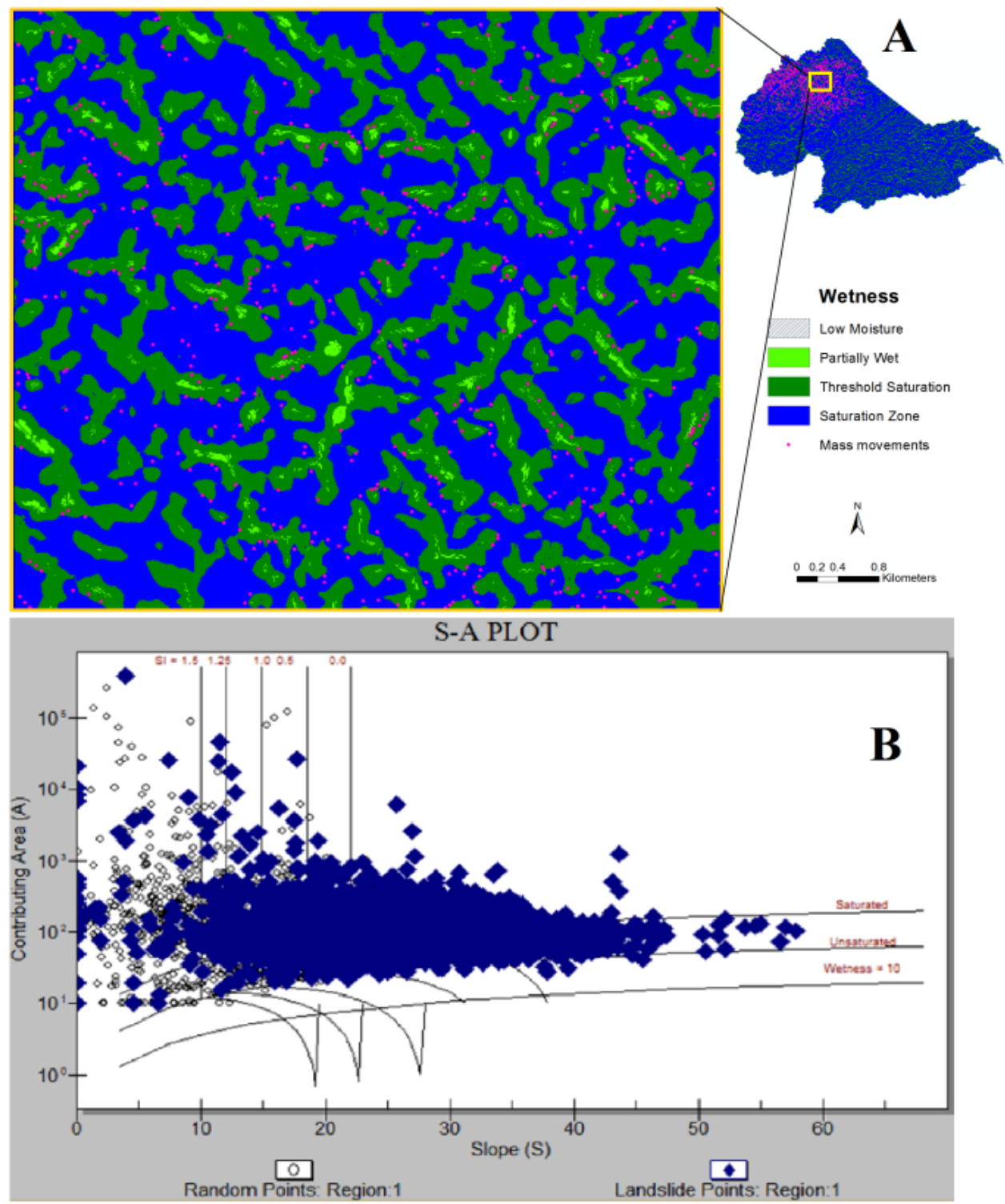

Source: Prepared by the authors. 
Therefore, it would be necessary introduce calibration regions selected on the basis of soil depth, soil texture and geotechnical characterization of soils in order to avoid that the slope angle distribution completely dominates the analysis in the absence of the relevant factor maps (JETEN et al., 2014) and to obtain better predictions of the SINMAP model (NERY and VIEIRA, 2012).

\section{Conclusions}

Based on the slope gradient, the soil moisture and the hydrogeological parameters, physically-based modelling SINMAP was carried out to calculate the map for the prone areas to slides at the Nova Friburgo municipality. It can be concluded that the interaction of relief, water balances and substrate can cause instability in wide areas of the territory.

From the three susceptibility scenarios tested with different ranges of dimensionless cohesion and internal angle of friction, the scenario 1 was shown to be the best predictor.

The model prediction skill was tested against the location of landslides occurring in 2011. Scenario 1 proved to be a good predictor with the dataset used. Thus, $90 \%$ of landslides were predicted to fail. That is, $55 \%$ were captured within the unstable zones, while $35 \%$ were predicted within zones with critical conditions for landslide occurrence (i.e., upper and lower threshold stability classes). However, it would be necessary to improve the registration of hydrological parameters and perform in situ and laboratory tests to provide reliable values of soil hydraulic and geotechnical parameters, which will allow the introduction of calibration regions to get better predictions.

Finally, the findings in this report will aid public health management and emergency preparedness efforts. Also, it may help to reduce the mortality burden in future landslide events. 


\section{Acknowledgements}

The authors thank to CAPES (Coordenação de Aperfeiçoamento de Pessoal de Nivel Superior), Brazil for the doctoral scholarship granted to the first author.

\section{References}

ABASCAL, L.; GONZALES BONORINO, G. Sedimentación coluvial e inestabilidad de laderas en los Andes de Tierra del Fuego. Revista de la Asociación Geológica Argentina, vol. 72, n. 4, 2015. pp. 470-481.

AMARAL, A. F. Mapeamento geotécnico aplicado à análise de processos de movimentos de massa gravitacionais: Costa Verde-RJ-Escala 1:10.000. Dissertação de Mestrado. Universidade de São Paulo, São Paulo, 2007. 210 p.

AVELAR, A. S.; COELHO NETTO, A. L.; LACERDA, W. A.; BECKER, L. B.; MENDONÇA, M. B. Mechanisms of the recent catastrophic landslides in the mountainous range of Rio de Janeiro, Brazil. Proceedings of the Second World Landslide Forum, Rome, 2011. pp. 1-5.

BARATA, F. E. Landslides in the tropical region of Rio de Janeiro. Proceedings of the $7^{\text {th }}$ Int. Conf. on Soil Mechanics and Foundation Engineering, Mexico, 1969. pp. 507-516.

BRABB, E. Innovative approaches to landslide hazard mapping. Proceedings of the $4^{\text {th }}$ International Symposium on landslides, Toronto, 1984. pp. 307324.

CALCATERRA, D.; DE RISO, R.; DI MARTIRE, D. Assessing shallow debris slide hazard in the Agnano Plain (Naples, Italy) using SINMAP, a physically based slope-stability model. In: W.A. Lacerda, M. E. Ehrlich, S.A.B, Fontoura, A.S.F. Sayao (Eds.). Landslides: evaluation and stabilization. Taylor and Francis Group, London, 2004. pp.177-183.

CAMARINHA, P. I.; CANAVESI, V.; ALVALÁ, C. S. Shallow landslide prediction and analysis with risk assessment using a spatial model in a coastal region in the state of São Paulo, Basil. Natural Hazards and Earth System Sciences, vol. 14, n. 9, 2014. pp. 2449-2468. 
CARDOZO, C. P.; MONTEIRO, A. M. V.; FREITAS; C. M.; LOPES, E. S. S. Intraurban differentials in the exposition and vulnerability to landslides: the Human Fatalities in the 2011 Nova Friburgo-RJ disaster. Proceedings of the First Brazilian Workshop on Assessment of Hazards, Vulnerability, Exposure and Disaster Risk Reduction, São José dos Campos, São Paulo, 2017. p. 40.

COELHO NETTO, A. L.; SATO, A. M.; AVELAR, A. S.; VIANNA, L. G.; ARAÚJO, I. S.; FERREIRA, D. L. C.; LIMA, P. H.; SILVA, A. P. A.; SILVA, R. January 2001: the extreme landslide disaster in Brazil. Proceedings of the Second World Landslide Forum, Rome, 2011. pp. 1-6.

COELHO NETTO, A. L.; FACADIO, A. C.; SILVA, R.; LIMA, P. H. Bioclimatic changes and landslide recurrence in the mountainous region of Rio de Janeiro: are we ready to face the next landslide disaster? Geophysical Research Abstracts, vol. 19, 2017.

COSTA NUNES, A. J. Landslides in soils of decomposed rock due to intense rainstorms. Proceedings of the VII International Conference on Soil Mechanics and Foundation Engineering, Mexico, 1969. pp. 547-554.

CUTTER, S.; BORUFF, B.; LYNN, W. S. Social Vulnerability to Environmental Hazards. Social Science Quarterly, vol. 84, n. 2, 2003.

CHUNG, C.; FABBRI, A. Validation of spatial prediction models for landslide hazard mapping. Natural Hazards, vol. 30, 2003. pp. 451-472.

DE CAMPOS, T. M. P.; ANDRADE, M. H. N.; VARGAS, E. A. Unsaturated Colluvium over rock slide in a forest site in Rio de Janeiro. Proceedings of the $6^{\text {th }}$ International Symposium on Landslides, Christchurch, 1992. pp. $1357-1364$.

DRM-RJ. Geological Map of Nova Friburgo. Technical Report, Mineral Resources; 1:50.000, Niterói, Rio de Janeiro. 1982. 71 p.

DRM-RJ. Cartografia Geotécnica de Aptidão Urbana, 1:10.000 de Nova Friburgo a "CGU do DRM” - Junho/2015. Relatório Técnico. Serviço Geológico do Estado do Rio de Janeiro, vol.5, 2015. 43 p

DOURADO, F.; ARRAES, T.; SILVA, M. F. O Megadesastre da Região Serrana do Rio de Janeiro - as causas do evento, os mecanismos dos movimentos de massa 
e a distribuição espacial dos investimentos de reconstrução no pós-desastre. Anuário do Instituto de Geociências, vol. 35, n. 2, 2012. pp. 43-54.

DOURADO, F.; ROIG, H. Mapas de susceptibilidade a escorregamentos rasos, usando os modelos SHALSTAB e SINMAP, da bacia do rio Paquequer Teresópolis -RJ. Caderno de Estudos Geoambientais, vol.4, n. 1, 2013. pp. 56-66.

EM-DAT. UN-ISDR- United Nations International Strategy for Disaster Reduction. 2013. A Resilient Planet, Resilient people. Technical Report, United Nations. Geneva, 2013.

GUIMARÃES, R. F. Utilização de um modelo de previsão de áreas susceptíveis a escorregamentos rasos com controle topográfico: Adequação e calibração em duas bacias de drenagem, Rio de Janeiro. Tese de doutoramento. Universidade Federal de Rio de Janeiro, Instituto de Geociências, Rio de Janeiro, 2000. 150 p.

GUZZETTI, F.; GALLI, M.; REICHENBACH, P.; ARDIZZONE, F.; CARDINALLI, M. Landslide hazard assessment in the Collazzone area, Umbria, Central Italy. Natural Hazards and Earth System Sciences, vol. 6, 2006. pp. 115-131.

IBGE. Censo Demográfico 2010. Site <https://cidades.ibge.gov.br/v4/brasil/rj/novafriburgo/panorama>, acessado em abril 2017.

JETTEN, V.; ALKEMA, D.; VAN WESTEN, C. J.; BRUSSEL, M. Development of the Caribbean handbook on disaster risk information management. Proceedings of the International Conference Analysis and Management of Changing Risks for Natural Hazards, Padua, 2014. pp. 1-10.

JONES F. O. Landslides in Rio de Janeiro and Serra das Araras escarpment, Brazil. Technical Report, U. S. Geological Survey, USA, 1973. 49 p.

KOZCIAK, S. Análise da estabilidade de vertentes na bacia do Rio MarumbiSerra do Mar-Paraná. Curitiba. Tese de doutoramento. Universidade Federal do Paraná, Programa Pós-Graduação em Geología, Curitiba, 2005. 151 p.

KURIAKOSE, S. L. Physically-based dynamic modelling of the effect of land use changes on shallow landslide initiation in the Western Ghats of Kerala, India. PhD thesis. University of Utretcht, Netherlands, 2010. 276 p. 
LOPES, S. S.; RIEDEL, P. S.; BENTZ, C. M.; FERREIRA, M. V. Calibração e validação do índice de estabilidade de encostas com inventário de escorregamentos naturais na bacia do rio da Onça na região da Serra de Cubatão, SP. Geociências, vol. 26, n. 1, 2007. pp. 83-95.

MARTHA, T. R.; KERLE, N.; JETTEN, V.; VAN WESTEN C. J.; KUMAR, V. Characterising spectral, spatial and morphometric properties of landslides for semi-automatic detection using object-oriented methods. Geomorphology, vol. 116, 2010. pp. 24-36.

MESINA, C.; SCARABELLI, S. A. Comparative analysis of terrain stability models for predicting shallow landslides in colluvial soils. Geomorphology, vol. 87, 2007. pp. 207-223.

MICHEL, G. P.; KOBIYAMA, M.; GOERL, R. F. Comparative analysis of SHALSTAB and SINMAP for landslide susceptibility mapping in the Cunha River basin, southern Brazil. Journal of Soils and Sediments, vol. 14, 2014. pp. 1266-1277.

MORRISSEY, M. M.; WIECZOREK, G. F.; MORGAN, B. A. A comparative analysis of hazard models for predicting debris flows in Madison County, Virginia. Technical Report 01-0067, U.S. Geological Survey, USA, 2001. 12 p.

MOURA, C. Catástrofe climática ocorrida na Região Serrana do Rio de Janeiro em 12/01/2011. Relatório técnico do Centro de Previsão de tempo e Estudos Climáticos, Brazil, 2011. 24 p.

NERY, T. Avaliação da susceptibilidade a escorregamentos translacionais rasos na bacia da Ultrafértil, Serra do Mar. Dissertação de Mestrado Universidade de São Paulo, Programa Pós-Graduação em Geografía Física, São Paulo, 2011. 170 p.

NERY, T. D. ; VIEIRA, B. C. Avaliação da suscetibilidade a escorregamentos rasos na bacia da Ultrafértil na Serra do Mar (Cubatão) por meio da aplicação do modelo SINMAP. Proceedings of the $9^{\circ}$ Simpósio Nacional de Geomorfologia, Rio de Janeiro, 2012. pp. 1-5.

NEUMAYER, E.; PLÜMPER, T. The gendered nature of natural disasters: the impact of catastrophic events on the gender gap in life expectancy, 1981- 
2002. Proceedings of the Association of American Geographers, vol. 97, n. 3, 2007. p. 551-566.

PACK, R. T.; TARBOTON, D. G.; GOODWIN, C. N. GIS-based landslide susceptibility mapping with SINMAP. Proceedings of the $34^{\text {th }}$ Symposium on Engineering Geology and Geotechnical Engineering. BAY, J. A. (Ed.). Logan, 1999. pp. 219-231.

PACK, R. T.; TARBOTON, D. G.; GOODWIN, C. N. SINMAP - A stability index approach to terrain stability hazard mapping. User's Manual (version is 1.0g). Utah State University, Utah, 2005. 73 p.

PRETI, F.; LETTERIO, T. Shallow landslide susceptibility assessment in a datapoor region of Guatemala (Comitancillo Municipality). Journal of Agricultural Engineering, vol. 46, n. 3, 2015. pp. 85-95.

RABONZA, M. L.; FELIX, R. P.; LAGMAY, F.; ECO, R. N. C.; ORTIZ, I. J. G.; AQUINO, D. T. Shallow landslide susceptibility mapping using high resolution topography for areas devastated by supertyphoon Haiyan. Landslides, vol. 13, 2016. pp. 201-210.

ROSSI, M; REICHENBACH, P. LAND-SE: software for statistically based landslide susceptibility zonation, version 1.0. Geoscientific Model Development, v. 9, p. 3533-3543, 2016.

SILVA, F. A. D. Análise da susceptibilidade a escorregamentos de massas na bacia hidrográfica do Rio Paquequer - Teresópolis - Estado do Rio de Janeiro, utilizando os modelos SINMAP e SHALSTAB. Dissertação de Mestrado. Universidade do Estado do Rio de Janeiro, Rio de Janeiro, 2006. 220 p.

TABALIPA, N. L.; FIORI, A. P. Influência da vegetação na estabilidade de taludes na bacia do rio Ligeiro (PR). Geociências, vol. 27, n. 3, 2008. pp. 387-399.

TARBOTON, D. G. A new method for the determination of flow directions and contributing areas in grid digital elevation models. Water Resources Research, vol. 33, n. 2, 1997. pp. 309-319.

TAROLLI, P.; TARBOTON, D. G. A new method for determination of most likely landslide initiation points and the evaluation of digital terrain model scale in terrain stability mapping. Hydrology and Earth System Science, vol. 10, 2006. pp. 663-677. 
TERHORST, B.; JAEGER, D. SINMAP Modeling of an active landslide area in the Swabian Alb. Geophysical Research Abstracts. vol. 17, 2015.

WOLLE, C. M.; PEDROSA, J. A. Horizontes de transição condicionam mecanismos de instabilização de encostas na Serra do Mar. Anais do Congresso Brasileiro de Geologia de Engenharia (ABGE), Santa Catarina, 1981. vol. 2, pp. 121-135.

WOLLE, C. M.; CARVALHO, C. S. Taludes Naturais. In: F. F. Falconi; Junior, A. N. (Org.). Solos do Litoral de São Paulo. ABMS, São Paulo, 1994. pp. 180-203. WORLD BANK. Site < http://data.wordbank.org/indicador/SP.POP.TOTL> , acessado em novembro de 2016.

ZAITCHIK, B. F.; VAN ES, H. M. Applying a GIS slope-stability model to sitespecific landslide prevention in Honduras. Journal of Soil Water Conservation, vol. 58, n. 1, 2003. pp. 45-53.

ZIZIOLI, D.; MEISINA, C.; VALENTINO, R.; MONTRASIO, L. Comparison between different approaches to modeling shallow landslide susceptibility: a case history in Oltrepo Pavese, Northern Italy. Natural Hazards and Earth System Science, vol. 13, 2013. pp. 559-573. 